\title{
Introduction: Religion and international relations in the twenty-first century
}

\author{
Jeffrey Haynes
}

Why do we need a handbook to examine the study of religion and international relations? Still in its relative infancy, the relationship between religion and international relations is an understudied subfield of research, with its origins in political science. At the same time, many scholars, policy makers and practitioners would agree that today the topic has global significance. When the topic of religion and international relations emerged as an interesting focus in the late 1970 s, concerns focused rather narrowly on the relationship between various 'religious fundamentalisms' and states. The 1979 revolution in Iran was the key catalyst for the topic to emerge. Forty years on, we can see that links between religion and international relations had already been around for a while in 1979. Links had emerged due to decolonisation, the Cold War and globalisation; and the subject area expanded in terms of geographic extensiveness to have a global focus - and in relation to the number of faiths with an input into international relations. The various relationships between religion and international relations help shape people's attitudes about how social, cultural and political systems are organised and operate, both domestically and internationally.

Until the late $1970 \mathrm{~s}$, relationships between religion and international relations seemed of relatively little importance for scholars, politicians, policy makers and most 'ordinary' people. Iran's revolution had a seismic international impact: 'radical political Islam' promptly became a key aspect of international relations, affecting Iran's relationship with the West, notably the United States, and with the rest of the Muslim world. Today, at the start of the third decade of the twenty-first century, the links between religion and international relations are myriad, both more pronounced and more varied. To understand these relationships, we need to recognise various topical and controversial issues, including the international importance of radical political Islam, transnational Hindu nationalism and Christian 'civilisationism'. While the first two are longstanding areas of focus, Christian 'civilisationism' has emerged relatively recently. It is topical and controversial in many European countries, as well as in the United States, Australia and Canada. Christian 'civilisationism' reflects the widespread political impact of Christian-orientated, right-wing populisms. In addition, there are important non-state international actors, such as the Organisation of Islamic Cooperation, the Vatican (and more widely the Roman Catholic Church), the United Nations and the European Union, which institutionally are concerned with religion and international relations. Each has established related formal and informal mechanisms systematically to engage with religious actors in international relations.

Many former colonies of the West gained their independence in the 15 years prior to Iran's 1979 revolution. Western colonisation was premised on the spreading of Western political ideas and ideologies which over time strongly influenced not only the political development of much of Africa, Asia, Latin America and the Caribbean, the Middle East and North Africa, but also greatly affected the 'structures' of international relations. After World War II the creation 


\section{Handbook on religion and international relations}

of the United Nations symbolised the prominence of secularism both in 'modern' Western countries and in their international relations.

Motivated by the pursuit of economic gain, the desire to spread civilisation, and an urge to Christianise the rest of the world, Europe's imperial powers spread the West's officially secular ideologies across international boundaries. This process continued until after World War II, when a rapid and conclusive process of decolonisation began. Prior to that, for 100 years from the mid-nineteenth to the mid-twentieth century, the vast European empires mainly run by the French and the British - had huge social, economic, political and religious impacts. Secular ideologies, such as, conservatism, liberalism, communism and nationalism, found numerous new adherents around the globe. Religion, on the other hand, was typically associated with 'traditional' behaviour and 'anti-modern' backwardness, and the new discipline of international relations, founded after World War I, chose to ignore it. As Europe's erstwhile colonial possessions gained their independence after World War II, their new nationalist governments were uniformly shaped and guided by Western political ideals. They also informed their foreign policies and international relations more generally, leaving no room for religion to influence outcomes.

Earlier, many independence movements in Asia, Africa and elsewhere found socialist and nationalist ideologies especially attractive. For four decades from the late 1940s, the Cold War conflict was over which Western ideology would prevail: liberal secularism or communist secularism. Religion was not in the frame. The end of the Cold War in the late 1980s encouraged many countries, including the erstwhile colonies of the Soviet Union, to look for their 'authentic' political values, mechanisms and structures; often, they turned to identity politics, with religion as a central component. Internationally, the early 1990s were contoured by the unexpected and deadly civil wars in former Yugoslavia, with combatants inspired not by communism but by mixtures of nationalism, ethnicity, culture and religion. And then came $9 / 11 \ldots$ from which the world has not yet recovered. 9/11 made radical political Islam a key issue for international relations, which has continued over the last 20 years. For many in the West, as well as for their secular nationalist and monarchical allies in the Middle East, radical political Islam had to be defeated at all costs: this was a new cold war. The West and their Middle East allies faced concerted attempts by al Qaeda, Islamic State and their allies to destabilise international relations. So far, the twenty-first century has been contoured by this relationship and, especially in this context, religion is impossible to ignore.

Francis Fukuyama had proclaimed in his book The End of History (1991) that the end of the Cold War marked the world's turning away from ideology. With the exception of Maoist beliefs that continued to guide rebel groups in a few 'developing' countries, such as Peru and Nepal, the age of ideology did, briefly, seem to be at an end. However, at the same time that ideology appeared to be in decline, various expressions of religious faith began reasserting themselves politically and socially in the form of revivalism or resurgence; many of these sought to spread their ideas across state boundaries and thus became an issue of international relations. Having been diminished in the West by the rise of secular politics and ideology and undercut globally by Western imperialism, religion began to restate itself both publicly and politically. Political and social movements in many former colonies, notably in Asia, Africa and the Middle East and North Africa, looked to religion to rediscover their political as well as their cultural identities both within countries and across state boundaries.

Reflecting these developments, a new scholarly, policy and popular focus on the relationship between religion and international relations ensued. The consequence was an expanded 
focus and purview - in terms of the depth in scope of inquiry - to look beyond the subject of within-territory political cleavages in order to analyse the complexity and multiplicity of forms by which religion and international relations interact. For example, the recent (albeit temporary) victories of Islamist political parties, consequential to the events of the Arab Uprisings, as evidenced with the Freedom and Justice Party in Egypt, Ennahda in Tunisia and the Party of Justice and Development in Morocco, highlighted increased significance of the interaction of religion, ideology and international relations in the Middle East and North Africa. In turn, this development was seen by many Western countries, including the United States and member states of the European Union, as a potentially serious challenge to international security; and as a result, their foreign policies turned away from a search for democracy to an acceptance of non-democratic rulers who would seek to repress Islamist politicians and political movements. However, despite their proclaimed adherence to the same religion, Islam, the rise to power of these differing, yet ideologically focused, parties highlighted their various religious dimensions and underlined how differently 'Islam' could be manifested ideologically and politically, both at home and in international relations. This divergence drove the need for an up-to-date and comprehensive handbook on questions of interaction of religion and international relations, with regard to, inter alia: international security, international conflict, international cooperation, foreign policy, secularisation, democratisation, the transnational spread of ideas and the nature of the international community. The result is the book that you are now reading - although various aspects of political Islam are by no means the only religion with which the book is concerned. To ensure full treatment of religion and international relations, the chapters of the book also bring into the picture Christianity, Buddhism, Judaism, Hinduism and secularism, among others.

The Handbook is divided into three parts: 'Core issues and topics', 'Debates and controversies', and 'Case studies'. Note that this is one person's take on the issue; others would no doubt have done it differently. I am delighted by the quality of the chapters comprising the Handbook. As editor, I was delighted to get the ready consent of some of the world's top scholars to write a chapter for the Handbook. There are too many to describe individually in this brief introduction. Actually, there is no need to do so: collectively, the chapters exhibit a dazzling array of knowledge, opinions, facts and ideas. I am confident that no one could read it without emerging with an advanced understanding of how religion and international relations interact, overlap and coalesce. To my fantastic colleagues who made this book possible: my deep and sincere thanks. 